\title{
Metabolomic Analysis of Dendrophthoe pentandra (L.) Miq. Leaves via UPLC-QToF-MS Coupled with Multivariate Data Analysis using PCA
}

\author{
$1^{\text {st }}$ Roihatul Mutiah ${ }^{1}, 2^{\text {nd }}$ Atina Yuliandari ${ }^{1}, 3^{\text {rd }}$ Rahmi Annisa $^{1}, 4^{\text {th }}$ Burhan Ma' arif ${ }^{1}$ \\ \{roiha@farmasi.uin-malang.ac.id ${ }^{1}$ \} \\ UIN Maulana Malik Ibrahim, Departement of Pharmacy, Faculty of Medical and Health Sciences, \\ Malang, Malang, Indonesia ${ }^{1}$
}

\begin{abstract}
Mango mistletoe (Dendrophthoe pentandra) is a semi-parasitic plant on a host that is potential as a medicinal plant. Thus, it is necessary to conduct metabolite profiling to determine the compounds contained in mango mistletoe leaves. This research aims to find out the difference of metabolite profile of mango mistletoe leaves obtained from Kediri, East Java; Pekalongan, Central Java; Batin Baru Mountain, Lampung and Tanjung, Selor Hilir in North Kalimantan. Extraction method with ultrasonic aid using $96 \%$ ethanol solvent with the ratio of $1: 10[\mathrm{~b} / \mathrm{v}]$ was used to obtain condensed extract of mango mistletoe leaves. The four extracts from different regions were analyzed using UPLC-QToF-MS/MS, mobile phase of mixture of water/formic acid of 99.9/0.1 [v/v] and acetonitrile/formic acid of $99.9 / 0.1[\mathrm{v} / \mathrm{v}]$ with a gradient elution system and a $\mathrm{C} 18$ stationary phase. The results of the analysis were then followed up by a chemometric analysis using PCA employing Minitab 17 software. There are differences in the metabolite among the four regions of extract acquisition. The grouping is based on similar metabolite which occurred in Kediri, East Java and Tanjung Selor Hilir, North Kalimantan. Allegedly, methyldioctylamine; scortechinone F; 3-Cyclohexyl-N(Ethoxycarbonyl)-L-Alanyl-N-[(4S, 5E, 7R)-7-carbamoyl-9-methyl-5-decen-4-yl]lysinamide; and Pheophorbide A were biomarker compounds based on the geographic origin.
\end{abstract}

Keywords: Metabolomics; Dendrophthoe pentandra (L) Miq.; UPLC-QTOF-MS/MS; PCA (Pricipal Component Analysis)

\section{Introduction}

The use of traditional medicine (herbal medicine) has been done since a long time ago. It even continues to be used and grows rapidly until now. $8 \%$ of Africans use some types of traditional medicine to treat illness. In 2008, markets around the world sell traditional medicine products that reach 60 billion US \$ [1][2][3]. Plant is one of raw materials sources of traditional medicine. Mango mistletoe is a semi-parasitic plant used to treat cough, diabetes, cancer, hypertension, and diuretics [4][5]. It can also stop the ringworm infection in children [6], and it is potential to be developed into immunomodulator [7]. Mango mistletoe leaves contain flavonol glycosides, quercitrine (quercetin-3-O-rhamnoside) that have antioxidant activity [8]. 
A plant that will be used as raw materials of medicinal plants should be standardized by controlling the quality of the metabolome. Metabolome is the total metabolites contained in plants. The composition is influenced by several factors including salinity, light, climate, temperature, weather, humidity, drought and nutrient [9]. Quality control of medicinal plants can be done through a metabolic analysis technique called metabolite profiling. This technique analyzes all analytes detected in the used samples and metabolites identification that is expressed differently in samples that have a clear classification [10]. Metabolite profiling uses a combination of several analytical techniques such as Gas Chromatography-Mass Spectrometry (GC-MS), Liquid Chromatography-Mass Spectrometry (LC-MS), or Capilary Electrophoresis-Mass Spectrometry (CE-MS). The techniques can provide detailed chromatographic profiles from the sample and both absolute and relative measurement numbers from the detected compounds [11]. Metabolomic is widely applied in many scientific disciplines, such as diagnostics of human diseases, biomarker discovery, nutrition, food safety, plant science and microbiology [12]. It is comparatively more precise and gives more informative data about the small metabolic molecules synthesized by the organism [13].

Ultra-Performance Liquid Chromatography-Mass Spectrometry (UPLC-MS) is the development of LC-MS techniques which can be utilized to analyze metabolite profiling. The technique of chromatography is able to present reliable, powerful results of chromatogram, high resolution, accurate measurement of mass and structural information as well as to detect a large number of metabolites in a sample of plants [13]. UPLC that is applied with MS is developed to be a powerful instrument to simultaneously identify and quantify chemical compounds contained in the raw materials of traditional medicines [14]. The component of UPLC-MS analysis results is analyzed using PCA of the chemometric analysis which can show the sample classification and characteristic of the compounds [15].

This research describes the metabolomic analysis in mango mistletoe using UPLC-QToFMS with a PCA multivariate analysis to determine metabolite profiles and discriminate samples in accordance with the difference of growing locations.

\section{Experimental Section}

\subsection{Materials}

Fresh and clean mango mistletoe was obtained from some areas, namely Kediri, East Java (225 masl); Pekalongan, Central Java (8 masl); Tanjung Selor Hilir, North Kalimantan (6 masl) and Gunung Batin Baru, Lampung (30 masl). It was dried in an oven with a temperature of $50{ }^{\circ} \mathrm{C}$ for 5-7 days before turning it into powder. The powder was separated according to the location of samples. The mango mistletoe that was processed to be samples had been identified as Dendrophthoe pentandra by Indonesian Institute of Sciences (LIPI)

\subsection{Instrumentation}

The instruments used were rotary evaporator (IKA, Ohio, USA), ultrasonic cleaner (Sonica Soltec, Milano, Italy), and Ultra Performance Liquid Chromatography-Quadrupole Time of Flight-Mass Spectrometry (UPLC-QToF-MS) (Waters, Massachusetts, USA).

\subsection{Procedure}

\section{Extraction of Plant Material}


50 grams of mango mistletoe powder was extracted using $500 \mathrm{ml}$ of etanol $96 \%$ by the aid (Merck, Darmstadt, Germany) by using ultrasonic waves for 20 minutes. The gained extract was filtered using filter papers, and was subsequently condensed using a rotary evaporator until it turned into solid extracts. Afterward, the solid extract was stored in a temperature of $-4{ }^{\circ} \mathrm{C}$ before having next treatment.

Ultra Performance Liquid Chromatography-Quadrupole Time of Flight-Mass Spectrometry (UPLC-QToF-MS) Analysis

The analysis of UPLC-QToF-MS employed UPLC-MS systems with QToF as the analysator and positive ESI as the ionization source with the Acquity C18 column 1,8 $\mu \mathrm{m} ; 2,1$ $\times 150 \mathrm{~mm}$. The applied Eluent was mixture between (A) Water (HPLC grade)/formic acid (Merck, Darmstadt, Germany) 99,9/0,1 [v/v]; (B) Asetonitril (Merck, Darmstadt, Germany)/formic acid 99,9/0,1 [v/v] and the system of gradient elution. The comparison is presented in table 1.

Table 1. The Ratio of Eluent Used

\begin{tabular}{lll} 
Time (minutes) & \% Eluent A & \% Eluent B \\
\hline 0,00 & 95,0 & 5,0 \\
2,00 & 75,0 & 25,0 \\
3,00 & 75,0 & 25,0 \\
14,00 & 0,0 & 100,0 \\
15,00 & 0,0 & 100,0 \\
19,00 & 95,0 & 5,0 \\
23,00 & 95,0 & 5,0
\end{tabular}

The source temperature was $100^{\circ} \mathrm{C}$ and the desolvation temperature was $350^{\circ} \mathrm{C}$. A $10 \mathrm{mg}$ extract sample was solved in $10 \mathrm{ml}$ volumetric flask with absolute methanol then, $5 \mu \mathrm{L}$ volumes were injected into UPLC-MS system. From chromatogram data, the area was in percentage. The chromatogram was processed using Masslynx version 4.1 software (Waters, Massachusetts, USA). The component identification was based on the ratio of measured $\mathrm{m} / \mathrm{z}$ in Masslynx and chemdraw version 12.0 (CambridgeSoft, Cambridge, USA).

\section{Statistical Analysis}

The identification data of extract component were classified based on the sample origin place and the percentages of its area were analyzed using Principal Component Analysis (PCA) to get loading plot and score plot. PCA was performed using Minitab 17 (Minitab Inc, Pensylvania, USA)

\section{Results and Discussion}

\subsection{UPLC-MS profiling of Dendrophthoe pentandra leaves metabolome}

UPLC-MS is a method to analyze metabolite profile with a high resolution, speed and sensitivity. It is also widely used for pharmaceutical analysis, such as long-chain fatty acid, 
underivatized amino acid and opiate in various matrixes [16]. The employed UPLC-MS uses an MS detector with ion source ESI (+) and MS analysator of Q-ToF.

The sample chromatogram was obtained by injecting sample into injection port which led to chromatography column and it created a component separation of injected extract. The research employed $\mathrm{C} 18$ or octadecyl silica as the column stationary phase, formic acid and water mixture 99.9/0.1 $[\mathrm{v} / \mathrm{v}]$ as the eluent and acetonitril/formic acid $99.9 / 0.1[\mathrm{v} / \mathrm{v}]$ with a gradient elution system, the ratio of both solvents was always changing [17]. Octadecyl silica was a stationary phase commonly used since it was able to separate low, medium and high polarity compounds [18]. The mixture of water/formic acid and acetonitrile/formic acid helped the separation process in the column efficiently and eluted the analyte in less than 1015 minutes [15] [19]. The use of this kind of UPLC-MS system produced chromatogram with polar compound at first and its polarity was gradually decreased [15]. After that, the sample of elution product went to MS detector.

In the MS system, the liquid sample was turned into drops through needle and was positively charged, since ESI that was used as ion source was the positive ones. Then, the ion was separated by Q-ToF analyzer. The product of the separation process was identified by the detector and presented as a chromatogram which was processed using the application of Masslynx 4.1 to present $\mathrm{m} / \mathrm{z}$ spectrum of each chromatogram peak [20]. Figure 1 below is the chromatogram of Dendrophthoe pentandra from each location where the sample obtained.

Each chromatogram peak indicated one compound. The application of Masslynx 4.1 was used to process the chromatogram to find out the $\mathrm{m} / \mathrm{z}$ spectrum. Therefore, the molecule formula of the interpretation product compound could be predicted. Then, chemspider website helped the researcher to find out the compound name of the prediction. When typing down the molecule formula, the total molecule should be taken away by one molecule. It was due to the fact that the ion source of positive ESI would add the $\mathrm{H}$ charge on the compound, so it was needed to subtract the total $\mathrm{m} / \mathrm{z}$ with the real mass of $\mathrm{H}$ atom that was 1.0078 . After finding out the name of the compound and structure, the measured and calculated $\mathrm{m} / \mathrm{z}$ were compared by drawing the compound structure using Chemdraw Ultra 12.0 [21]. If the difference was $\leq$ 0.0005 then the peak was belong to the predicted compound [22]. The result of chromatogram data interpretation was presented in the following Table 2. The data showed that 76 compounds were from Tanjung Selor Hilir, North Borneo; 17 compounds were from Kediri, East Java; 61 compounds were from Gunung Batin Baru, Lampung; and 56 compounds were from Pekalongan, Central Java.

Principal Component Analysis

The PCA multivariate data analysis is one of chemo metric analyses commonly used for multicomponent analysis [20]. It analyzes the data from chromatogram in the form of compound name and $\mathrm{m} / \mathrm{z}$ value using Minitab 17 software. The data for PCA analysis consisted of compound names found in area presented in percentage from four sampling places. The results were Score Plot and Loading Plot presented in Figure 2 and Figure 3. The score plot indicated the similarity among samples. Similar samples went to a same group or a close point. Plot loading described the relation among variables - the origin and the new ones [23]. It was used to analyze the contribution of each metabolite on PC (Principal Component), so the furthest component from the group significantly contributed on the difference among groups. The result of PCA analysis on the Dendrophthoe pentandra leaves extract showed $89.6 \%$ total variants $(\mathrm{PC} 1=59.8 \%$ dan $\mathrm{PC} 2=29.8 \%)$. Figure 2 shows the pattern of sample grouping. The sample from Kediri, East Java (K) was in the same group with the sample from Tanjung Selor Hilir, North Borneo (TSH). On the other hand, the samples from Gunung Batin 
Baru, Lampung (GBB) and Pekalongan, Jawa Tengah (P) were not grouped. It indicated that the type of metabolite from K and TSH were similar compared to that of GBB and P.

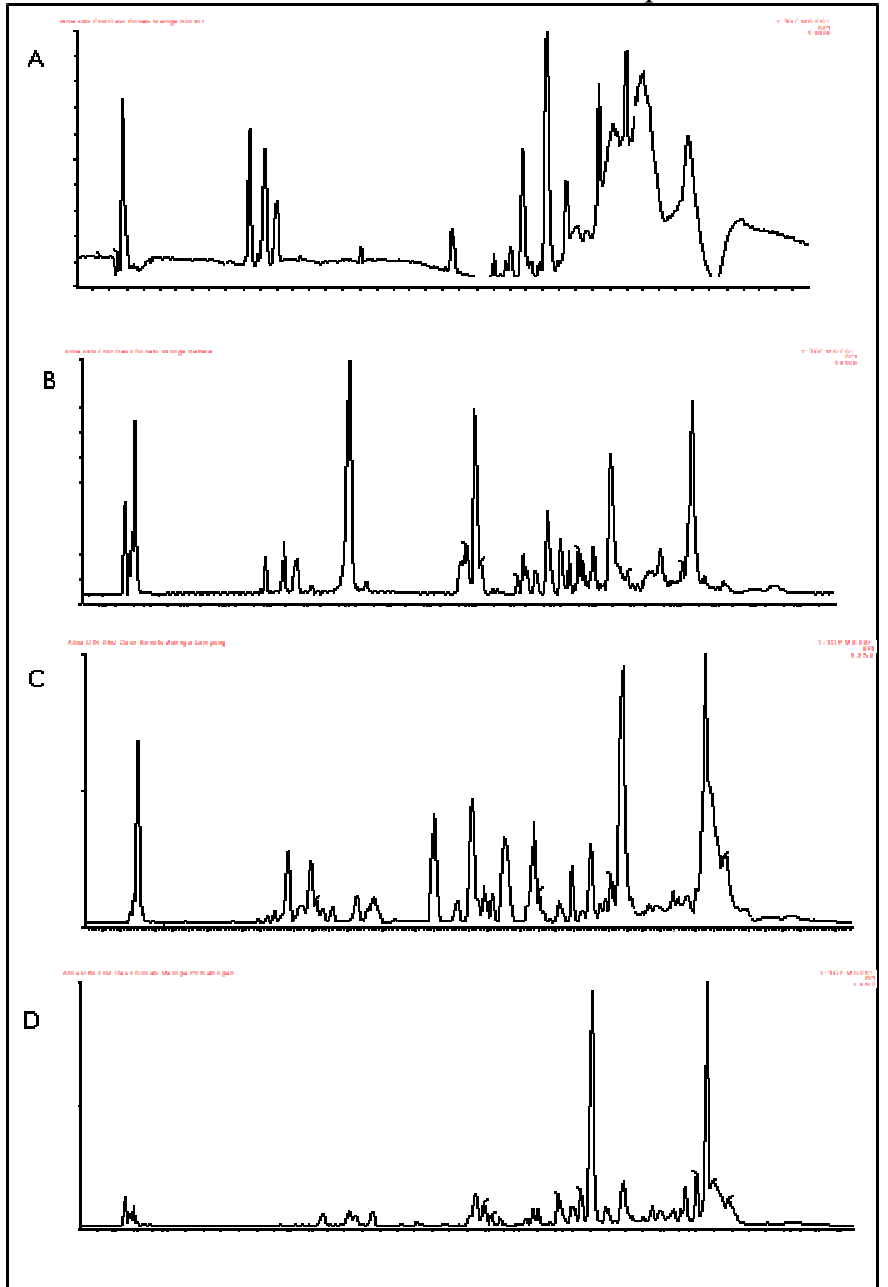

Figure 1. UPLC-MS Chromatogram of Dendrophthoe pentandra leaves extract. A) Chromatogram of Dendrophthoe pentandra leaves extract from Kediri, East Java. B) Chromatogram of Dendrophthoe pentandra leaves extract from Tanjung Selor Hilir, North Borneo. C) Chromatogram of Dendrophthoe pentandra leaves extract from Gunung Batin Baru, Lampung. D) Chromatogram of Dendrophthoe pentandra leaves extract from Pekalongan, Central Java 


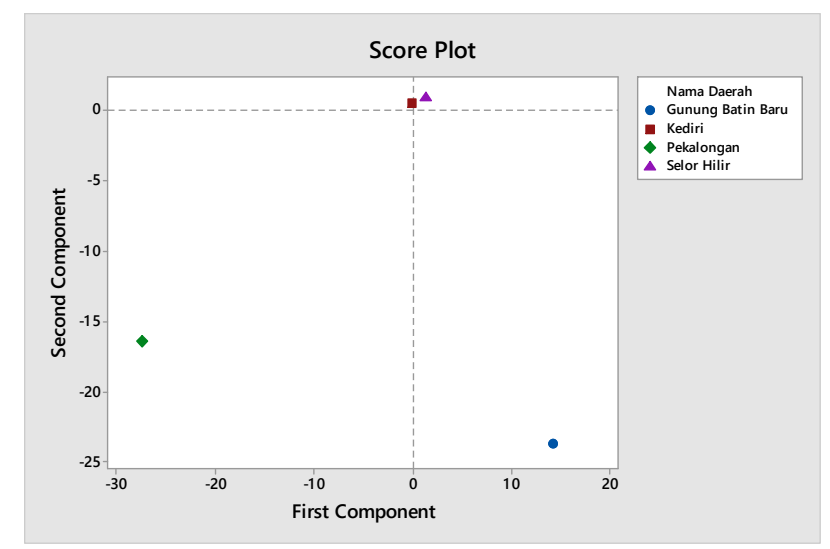

Figure 2. Scoring plot which showed the metabolic grouping from Kediri, East Java and Tanjung Selor Hilir, Kalimantan Utara.

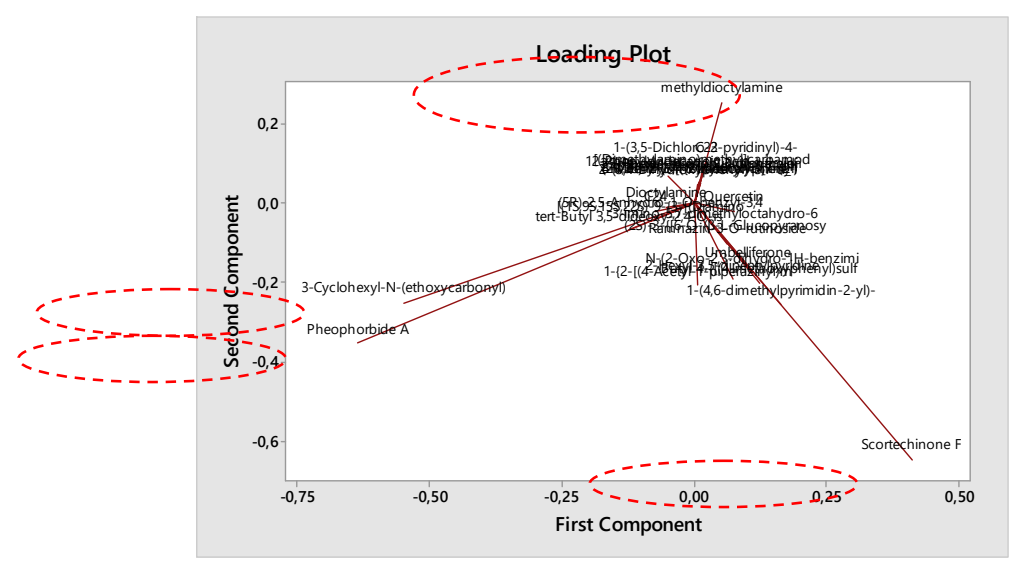

Figure 3. Plot loading which showed the findings of several identifying compounds

The grouping according to metabolic resemblance could be influenced by plants environment or other abiotic factors like weather, climate or rainfall [24]. TSH and K were estimated to have similar abiotic factors. Rainfall and average temperature of these areas were relatively similar; K's rainfall was $2.043 \mathrm{~mm}$ and the average temperature was $24.4^{\circ} \mathrm{C}$. Meanwhile, TSH's rainfall was $2.738 \mathrm{~mm}$ and the average temperature was $26.8^{\circ} \mathrm{C}$. Although the temperatures of both areas were different, those areas were in the same main climate: type A climate. According to Koeppen, A climate is tropical forest with extreme weather along the year [25]. Moreover, $\mathrm{K}$ and TSH have the dominant soil type similarity that is alluvial soil type. The previous sub chapter explained that this type of soil has good fertility level. With several similarities of abiotic factors from those areas, it could be inferred that those areas' metabolic were almost the same.

Figure 3, plot loading shows the hypothesis of biomarker compound from the extracts of mango mistletoe leaves which were collected from several areas. In the plot loading, there were four metabolics, they were methyldioctylamine; scortechinone F; 3-Cyclohexyl- $N$ (ethoxycarbonyl)- $L$-alanyl- $N-[(4 \mathrm{~S}, 5 \mathrm{E}, 7 \mathrm{R})-7-$ carbamoyl-9-methyl-5-decen-4-yl]- $L-$ 
lysinamide; and Pheophorbide A which were estimated to be able to be used as identifying compound for grouping basics for mango mistletoe leaves according to their geographical origin. Those four compounds were dominant or major compounds from their areas. Methyldioctylamine compound was from Tanjung Selor Hilir with area percentage of 11 . $448 \%$; 3-Cyclohexyl- $N$-(ethoxycarbonyl)- $L$-alanyl- $N$-[(4S,5E,7R)-7- carbamoyl -9-methyl-5decen-4-yl]-L-lysinamide compound were from Pekalongan (21.11\%) and Tanjung Selor Hilir (2.54\%); Pheophorbide A compound was from Pekalongan (23.96\%); 1-(4,6-dimethyl pyrimidin-2-yl)-3-(4-methyl-3-nitrophenyl) guanidine compound was from Gunung Batin Baru (13.57\%), Pekalongan (5.20\%), and Tanjung Selor Hilir (10.14\%); and Scortechinone F compounds were from Gunung Batin Baru $(21.76 \%)$ and Tanjung Selor Hilir $(0.82 \%)$. The spectras of those compounds were shown in figure 4. One of those identifying compound had scortechinone F compound. Scortechinone F compound was from the group of xanthones compound. It had been found in Garcinia scortechinii plant [26]. There was not much information about this compound. Recently, there are several kinds of Scortechinone compound; they are Scortechinone U, Scortechinone J, Scortechinone F, Scortechinone E, Scortechinone H, Scortechinone I [27]. 


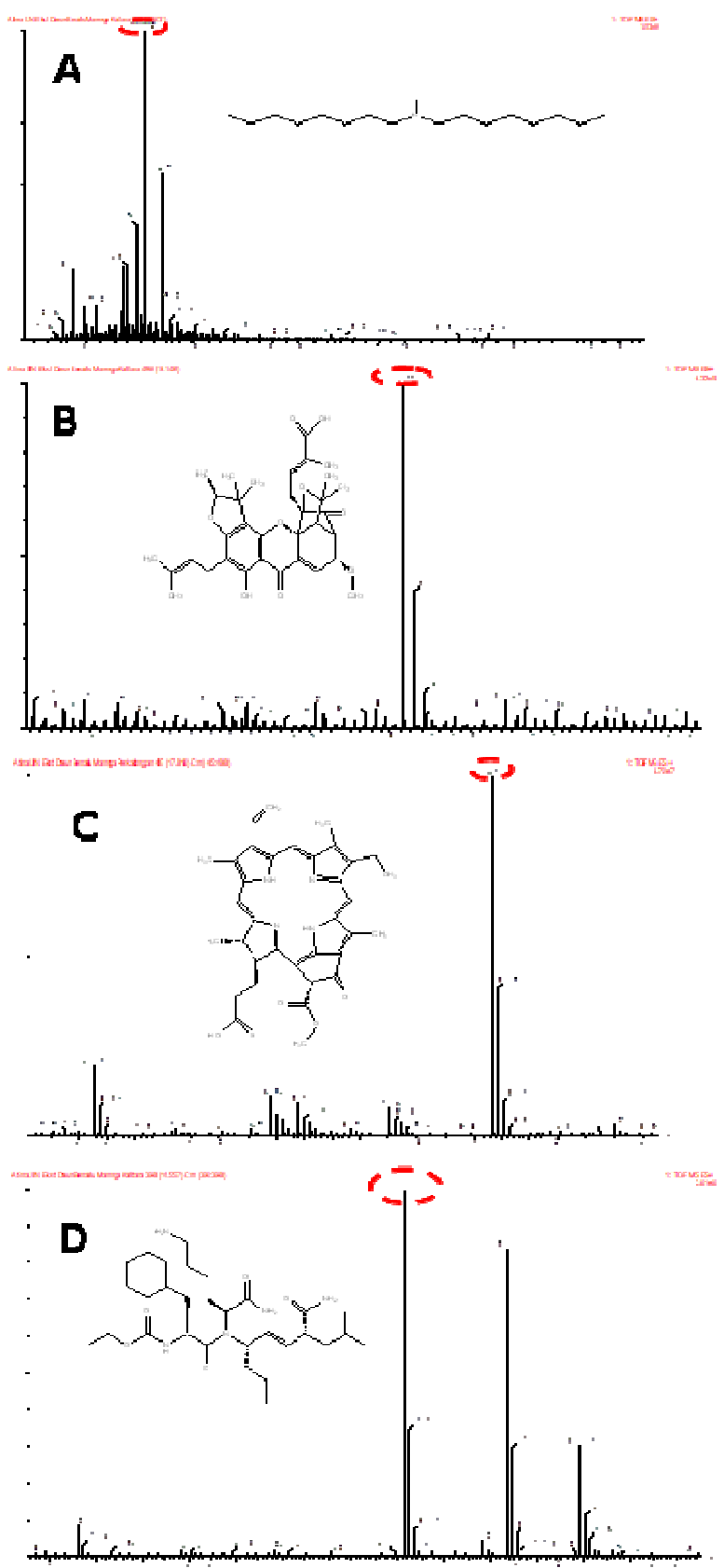

Figure 4. The spectras of biomarker compounds. A) methyldioctylamine; B) Scortechinone F; C) Pheophorbide A; D) 3-Cyclohexyl-N-(ethoxycarbonyl)-L-alanyl-N-[(4S,5E,7R)-7-carbamoyl-9-methyl-5decen-4-yl]-L-lysinamide

\section{Conclusion}


There are some differences of metabolic profile of mango mistletoe leaves extract obtained from Kediri, East Java; Pekalongan, Central Java; Gunung Batin Baru, Lampung; and Tanjung Selor Hilir, North Kalimantan. The marker compounds obtained were methyldioctylamine compound from Tanjung Selor Hilir, North Kalimantan; 3-Cyclohexyl- $N$ (ethoxycarbonyl)- $L$-alanyl- $N$-[(4S,5E,7R)-7-carbamoyl-9-ethyl-5-decen-4-yl]- $L$-lysinamide compound was from Pekalongan, Central Java and Tanjung Selor Hilir, North Kalimantan; Pheophorbide A compound was from Pekalongan, Central Java; 1-(4,6-dimethylpyrimidin-2yl)-3-(4-methyl-3-nitrophenyl)guanidine compound was from Gunung Batin Baru (Lampung), Pekalongan (Central Java), and Tanjung Selor Hilir (North Kalimantan); while Scortechinone $\mathrm{F}$ compound was from Gunung Batin Baru (Lampung) and Tanjung Selor Hilir (North Kalimantan).

Acknowledgements. The researchers express their deep gratitude to the Directorate of Islamic Higher Education (DIKTIS), Ministry of Religious Affairs for the research funding support from the Science Integration so the research can be completed. This paper in conjuction with the 1st International Conference On Islam, Science, And Technology (ICONIST) 2018, Malang, East Java.

\section{References}

[1] Tilburt, J.C., Kaptchuk, T.J., "Herbal Medicine Research and Global Health: an Ethical Analysis", Bulletin of the World Health Organization, vol. 86 (8), pp. 577-656. 2008

[2] World Health Organization (WHO), Assessment and monitoring of antimalarial drug efficacy for the treatment of uncomplicated falciparum malaria, Geneva (WHO/HTM/RBM/2003.50.), 2003

[3] Bodeker G., Willcox M.L., "Conference report: the first international meeting of the Research Initiative on Traditional Antimalarial Methods (RITAM)", J. Altern. Complement. Med., 6 (2), 195207.

[4] Endharti, A. T., Wulandari, A., Listiyana, A., Norahmawati, E., and Permana, S., "Dendrophthoe pentandra Extract Effectively Inhibit Inflamation, Proliferation, and Induces p53 Expression on Colitis-Associated Colon Cancer, BMC". Complement. Altern. Med., 16, 1-8. 2016

[5] Mutiah R, Listiyana A, Indradmojo C, Griana TP, Dwi HH and Atmaja RR. "Induction of Apoptosis and Phase-Cell Cycle Inhibition of G0-G1, S, G2-M of T47D Breast Cancer Cells on Treatment with Ethyl Acetate Fraction of Jackfruit Parasite Leaves (Macrosolen cochinensis)". Journal of Applied Pharmaceutical Science, vol. 07 (10). pp. 138-143. 2017.

[6] Shanavaskhan, A. E., Sivadasan, M., Alfarhan, A.H., and Thomas, J., "Ethnomedicinal Aspects Of Angiospermic Apiphytes And Parasites Of Kerala, India, Indian”, J. Traditional Knowledge, vol. 11 (2), pp. 250-258, 2012

[7] Ang, H. Y., Subramani, T.S., Yeap, S.K., Omar, A.R., Ho, W.Y., Abdullah, M.P., and Alitheen, N.B., "Immunomodulatory effects of Potentilla indica and Dendrophthoe pentandra on Mice Spenocytes and Thymocytes", Exp. Ther. Med., vol. 7, pp.1733-1738, 2014

[8] Artanti, N., Firmansyah, T., and Darmawan, A., "Bioactivities Evaluation of Indonesian Mistletoe (Dendrophthoe pentandra) Leaves Extract", Journal of Applied Pharmaceutical Science (JAPS), vol. 2 (1), pp. 24-27. 2012

[9] Wang, W., Vinocur, B., Alatman, A., "Plant response to drought, salinity and extreme temperatires: tward genetic engineering for stress tolerance", Planta, vol. 218, pp. 1-14. 2003

[10] Dettmer, K., Aronov, P. A. and Hammock, B. D., "Mass Spectrometry-Based Metabolomics", Mass. Spectrom, vol. 26, pp.51-78. 2007 
[11] O'Gorman, A., Metabolic Profiling and Fingerprinting for the Detection and Discrimination of Mechanical Damage in Mushroom (Agaricus bisporus) during Storage [Doctoral Thesis]. Dublin, Ireland: Dublin Institute of Technology. 2010

[12] Schuhmacher, R. And Krska, R., "Metabolomics and metabolite profiling." Anal Bioanal Chem, vol. 405 pp.5003-5004, 2013.

[13] Kumar, B., Prakash, A., Ruhela, R.K., Medhi, B,. "Potential of metabolomics in preclinical and clinical drug development". Pharmacological Reports, vol. 66, pp.956-963, 2014

[14] Zhao, Y. Y., Lin, R. C., "UPLC-MS application in disease biomarker discovery: The discovery in proteomics to metabolics", Chemico-Biological Interactions, vol. 215, pp.7-16, 2014

[15] Chan, E.C.Y., Yap, S.L., Lau, A.J., Leow, P.C., Toh, D.F., Koh, H.L., "Ultra-performance liquid chromatography/time-of-flight mass spectrometry based metabolomics of raw and steamed Panax notoginseng," Rap. Commun. Mass. Spectrom., vol. 21, pp. 519-528. 2007

[16] Farag, M. A., Rasheed, D. M., Kropf, M. and Heiss, A.G., "Metabolite Profiling in Trigonella Seeds Via UPLC-MS and GC-MS Analyzed Using Multivariate Data Analysis", J. Anal Bioanal Chem., vol. 408, pp. 8065-8078, 2016

[17] Hampel, D.; York, E.R. and Allen, L.H., "UUPLC-MS for the Rapid, Simultaneous Analysis Of Thiamin, Roboflavin, Flavin Adenine Dinucleotide, Nicotinamide and Pyridoxal in Human Milk," Journal of Chromatography B, Elsevier., vol. 903, pp. 7-13. 2012

[18] Mulja, M. dan Suharman, Analisis Instrumental, Surabaya: Airlangga University Press, 1995

[19] Gandjar, I.G., dan Rohman, A., Kimia Farmasi Analisis. Cetakan ke 7, Yogyakarta: Pustaka Pelajar. 2010,

[20] Silva, C. B.P.; Julio, I.P.; Donadel, G.E.; and Martins, I., "UPLC-MS/MS method for simultaneous determination of cyclophosphamide, docetaxel, doxorubicin and 5-fluorouracil in surface samples", Journal of Pharmacological and Toxicological Methods, vol. 82, pp. 68-73. 2016

[21] Anissa. Kajian Metabolomik Rimpang Kunyit Menggunakan Kromatogafi Cair-Spektroskopi Massa [Skripsi]. Bogor: Departemen Kimia Institut Pertanian Bogor (IPB). 2012.

[22] Skoog, D.A.; West, D.M.; Holler, F.J. and Crouch, S.R. Fundamentals of Analytical Chemistry. Eighth Edition. Belmont, CA: Thomson Brooks/Cole. 2004.

[23] Brenton, A.G. dan Godfrey, A.R. "Accurate Mass Measurement: Terminology and Treatment of Data". Journal of American Society for Mass Spectrometry (JASMS), 21, 1821-1835. 2010

[24] Esbesen, K. H.; Guyot, Dominique; dan Houmoller, L.P. 2002. Multivarite Data Analysis: In Practice: an Introduction to Multivariate Data Analysis and Experimental Design 5th Edition. Demark: Aalborg University Press, Esbjerg.

[25] Heuerger, A.L.; Broeckling, C.D.; Kirkpatrick, K.R. and Prenni, J.E. "Applicaton of Non Targetted Metabolite Profiling to Discover Novel Markers of Quality Traits in An Advanced Population of Malting Barley”. Plant Biotechnology Journal, vol. 12, pp. 147-160. 2014.

[26] Tjasyono HK, B. Klimatologi. Edisi ke-2. Bandung: ITB Press. 2004.

[27] Sukpondma, Y.; Rukachaisirikul, V.; dan Phongpaichit, S. "Xanthones and sesquiterpene derivates from the fruit of Garcinia scortechinii". J. Nat. Prod.Vol 68, No 7, pp. 1010-1017. 2005. 